fungal specific PCR primers. All fungi are identified by DNA sequencing of the ITS locus. Additionally, fungi are evaluated for their mycorrhizal potential through assays of symbiotic germination of Vanilla seeds. The results support the bioprospecting focused on the con- servation of these valuable plant genetic resources, as well as the development of sustainable cultivation techniques. This study is also an important contribution to the incipient studies of microbial diversity in the megabiodiverse country of Colombia.

\title{
Hongos micorrízicos de orquídeas en poblaciones naturales en los departamentos del Valle del Cauca y Antioquia, Colombia
}

\author{
Ana Teresa Mosquera-Espinosa ${ }^{1,2^{*}}$, Paul Bayman ${ }^{3} \&$ J. Tupac Otero ${ }^{1,4,5}$
}

${ }^{1}$ Research Group in Orchids, Ecology, and Plant Systematics, Universidad Nacional de Colombia, Palmira, Colombia;

${ }^{2}$ Biology Program, Pontificia Universidad Javeriana, Cali, Colombia; ${ }^{3}$ Biology Department, University of Puerto

Rico-Rio Piedras; ${ }^{4}$ Biological Sciences Department, Universidad Nacional de Colombia, Palmira, Colombia;

${ }^{5}$ Environmental Studies Institute (IDEA Palmira), Universidad Nacional de Colombia, Palmira, Colombia

*Autor para correspondencia: fitopatologia@hotmail.com

En Colombia existe una amplia diversidad de especies de orquídeas (cerca de 3.500 especies), muchas aún no descritas. También, dentro de la diversidad se incluyen los hongos micorrízicos del género-forma Rhizoctonia y sus teleomorfos en los géneros Thanatephorus, Sebacina, Ceratobasidium y Tulasnella. En algunas orquídeas terrestres de zonas templadas se asocian con otros grupos de hongos. Para esta zona tropical es poco lo que se conoce sobre sus hongos micorrízicos y aún no es claro si la mayoría de orquídeas, se asocian con los mismos micosimbiontes o si existen otros cumpliendo tal actividad. Para contestar esta pregunta se tomaron secciones de raíces micorrizadas, de las cuales se aislaron y cultivaron hongos para secuenciar ADN de la región ITS nuclear ribosomal. Igualmente se realizaron ensayos de germinación simbiótica. Estudios desarrollados por el Grupo mostraron a Ceratobasidium como el género de hongo micorrízico predominante en algunas orquídeas de Colombia con hábito terrestre, epífito y hemiepifítico (Vanilla spp., en raíces terrestres). Las secuencias de hongos de orquídeas epífitas se relacionaron estrechamente con secuencias de hongos de orquídeas epífitas de Puerto Rico. Lo anterior sugiere que Ceratobasidium está presente como micorrízico en orquídeas independiente del hábitat de la planta y su ubicación geográfica.

\section{Selección de rasgos florales en Rodriguezia granadensis (Lindl.) Rchb.f. (Orchidaceae): estudio de la eficacia biológica en una especie polimórfica}

\author{
Nhora Helena Ospina-Calderón ${ }^{1,2 *}$, J. Tupac Otero ${ }^{2,3,4} \&$ R. L. Tremblay ${ }^{5}$
}

'Facultad de Ciencias Naturales, Programa de Ecología, Fundación Universitaria de Popayán, Popayán, Colombia; ${ }^{2}$ Grupo de Investigación en Orquídeas, Ecología y Sistemática Vegetal. Universidad Nacional de Colombia Sede

Palmira, Colombia; ${ }^{3}$ Facultad de Ciencias Agropecuarias, Departamento de Ciencias Biológicas, Universidad Nacional de Colombia Sede Palmira, Colombia; ${ }^{4}$ Instituto de Estudios Ambientales IDEA, Palmira, Colombia. Universidad Nacional de Colombia Sede Palmira, Colombia; ${ }^{5}$ Departamento de Biología, Universidad de Puerto Rico, Humacao; *Autor para correspondencia: nhora-helena@yahoo.com

La supervivencia de las especies depende en parte de su dinámica poblacional y sus característica fenotípicas. El proceso de selección natural es un mecanismo que puede influenciar la producción de progenies. Se estudió la biología y demografía de dos poblaciones de Rodriguezia granadensis (Lindl.) Rchb. f. en la zona de la Reserva Forestal Bosque de Yotoco y en el corregimiento El Dorado, Colombia, 
para determinar si hay variación en la adecuación Darwiniana de dos poblaciones. La población de Yotoco presenta dos fenotipos claramente diferenciables por el color (Rosa y Blanco), mientras que en Centenario se encontró solamente el fenotipo Blanco; las flores pueden presentar o no néctar independiente de su fenotipo. Las ofertas florales de $R$. granadensis se encuentran en el callo del labelo y el nectario de ducto que contiene el espolón o sinsépalo, recubierto por un epitelio glandular compuesto por osmóforos y nectarios. $R$. granadensis es polinizada por Eulaema sp. que la visita en busca de alimento, es autoincompatible, xenogama obligada y dependiente del polinizador. Mediante simulaciones con matrices demográficas de transición a 50 años y 500 repeticiones se encontró que ambas poblaciones y fenotipos tienden a la extinción en un plazo de 25 años. No se encontraron diferencias entre la adecuación Darwiniana, de los fenotipos de estudio por lo que no se puede probar la existencia de selección fenotípica sobre los caracteres florales. La variación de la especie puede deberse a la deriva génica o la selección dependiente de la frecuencia y la ecología cognitiva del polinizador.

\title{
Distribution patterns of Cuitlauzina pendula La Llave \& Lex (Orchidaceae) over its phorophytes at the 'Barranca de Cupatitzio' National Park, in Uruapan, Michoacán, México
}

\author{
Verónica A. Pérez-Decelis ${ }^{1}$, Carlos Gómez-Alonso ${ }^{2}$ \& Irene Ávila-Díaz ${ }^{3 *}$
}

${ }^{1}$ Programa Institucional de Maestría en Ciencias Biológicas de la Universidad Michoacana de San Nicolás de Hidalgo, Facultad de Biología, Universidad Michoacana de San Nicolás de Hidalgo (UMSNH), Edif. R planta baja, Posgrado. Ciudad Universitaria, 58040 Morelia, Michoacán, México; ${ }^{2}$ Centro de Investigación Biomédica de Michoacán, IMSS, Camino de las Arboledas No. 300, Fracc. Exhda. San José de la Huerta, 58341 Morelia, Michoacán, México; ${ }^{3}$ Facultad de Biología, Universidad Michoacana de San Nicolás de Hidalgo (UMSNH),

Edif. R planta baja, Ciudad Universitaria, 58040 Morelia, Michoacán, México

*Author for correspondence: iaviladiaz5@gmail.com

Cuitlauzina pendula La Llave \& Lex. is an epiphytic, endemic, and threatened Mexican orchid. This research was carried out at the 'Barranca de Cupatitzio' National Park in Uruapan, Michoacán. The objectives of this study were to 1) evaluate vertical and horizontal distribution of $C$. pendula and 2) determine if there are preferences, taking into account the age class in the position on the tree (side, up, and down), substrate type (bark, moss, and lichen), as well as the orientation (N, S, E, W). Two quadrants of $12.5 \times 25 \mathrm{~m}$ were established in homogeneous conditions of oak-pine forest, and two more quadrants of the same size at a pine-oak forest. Records were made for the host type, number of individuals in the different zones of the phorophytes (tree stem, tree canopy, and the respective sections of the tree canopy), age classes (seedlings, juveniles, and adults), position on the branches, substrate type, and orientation. Results of this study show greater abundance of $C$. pendula on the tree canopy $(91.6 \%)$ and on the middle part of the branches $(43.9 \%)$. The population is mainly represented by the adult class $(62.3 \%)$ with more individuals on the lateral position $(54.5 \%)$ and on the bark-moss substratum (76.7\%), the east (19\%), and north position (16.5\%). Cuitlauzina pendula has a significant greater number of individuals in the oak-pine forest than in the pineoak forest. In light of these results, this study could be employed as a tool to generate appropriate strategies of management that promote the conservation of this species. 